\title{
QUALIFICATION REQUIREMENTS FOR FOREIGN SUPPLIERS IN PUbLIC Procurement - EVIDENCE FROM THE CZECH REPUbliC
}

\section{Martin Vyklický ${ }^{1}$, Petr Man ${ }^{2}$, Rudolf Franz Heidu ${ }^{3}$, Radek Jurčík ${ }^{4}$}

\begin{abstract}
Qualification requirements for foreign suppliers in Public Procurement (PP) are quite different in each European Union (EU) member state. The most complex requirements for foreign suppliers in the context of public purchases are included in the Czech PP law. The aim of this paper is to make an overview of the problem of qualification requirements for foreign suppliers in the PP law of the CR. Its sub-objectives are the identification and explanation of solutions to the problem in the PP legislation of neighboring countries of the CR that are also members of the EU. The methodological part of the contribution is based mainly on the analysis and critical evaluation of the current state of legal issues relating to the proof of qualification of foreign suppliers in PP orders of the CR; with examples of fairly extensive decision-making practices of the Office for the Protection of Competition and law courts, including the jurisprudence of the European Court of Justice. The paper highlights the unnecessary complexity of qualification requirements that, on purely formal grounds, inhibits submissions of tenders from potential foreign suppliers that would otherwise be able to submit a bid for a public contract without any problems whatsoever. The authors are using and applying a comparative-legal method in the context of the comparison of the PP legislation of neighboring countries of the CR that are also members of the EU. The case study of foreign suppliers bidding for above-threshold public tenders in the $\mathrm{CR}$ at the minimum legal requirements of the contracting authority (CA) for proof of qualification, the comparation study with selected EU countries or analysis of the development of the proportion of public contracts awarded to foreign suppliers in 2010-2014 shows that there is legislation uncertainty in EU PP law that should be reduced and simplified on an EC basis.
\end{abstract}

\section{Keywords}

Qualification Requirements, Public Procurement, Foreign Supplier

\footnotetext{
${ }^{1}$ Department of Law and Social Sciences, Faculty of Business and Economics, Mendel University in Brno, Zemědělská 1, 61300 Brno, Czech Republic, e-mail: xvyklick@node.mendelu.cz.

${ }^{2}$ Department of Law and Social Sciences, Faculty of Business and Economics, Mendel University in Brno, Zemědělská 1, 61300 Brno, Czech Republic, e-mail: petr.man@mendelu.cz.

${ }^{3}$ Department of Law and Social Sciences, Faculty of Business and Economics, Mendel University in Brno, Zemědělská 1, 61300 Brno, Czech Republic, e-mail: xheidu@ node.mendelu.cz.

${ }^{4}$ Department of Law and Social Sciences, Faculty of Business and Economics, Mendel University in Brno, Zemědělská 1, 61300 Brno, Czech Republic, e-mail: radek.jurcik@mendelu.cz.
} 


\section{Introduction}

PP, its efficiency and purpose of its use are, in the $\mathrm{CR}$, the EU or worldwide often discussed as a problem. Politicians, CAs but also the professional community continue to try to find the most effective rules and systems for transparent and non-discriminatory PP that will be able to open up the PP market to all potential and qualified suppliers. This paper is territorially based on the PP of the EU, resp. EEA (European Economic Area). Due to the fragmentation of each EU member's PP legislation, it is highly complicated for suppliers from one EU (or EEA) member state to submit a bid into a tender that is announced by a CA from another EU (or EEA) member state. European PP directives attempt to unify this fragmentation and should provide a legislation framework for EU members. We should mention that autonomy exists for EU members to set their own qualification requirements to suppliers due to the PP directives. Every member state is able to set qualification requirements in PP for suppliers at its discretion. The consequence of this discretion is that there are significant differences in the PP legislation of each EU member, with the result that there is a very high probability that, even if a supplier meets, for example, the basic qualification requirements in its country of origin, such a supplier does not necessarily meet the basic qualification requirements in a foreign EU country.

The authors highlight that, in the long term, a solution to the above-mentioned problem needs to be intensively dealt with by the government of the CR. This paper is interested in the differences between the PP qualification requirements of each EU member, along with detailed analysis of CR PP legislation in the form of verification impacts to suppliers from other EU members and their ability to participate in CR PP tenders. The authors based the analysis on data obtained from the Journal of Public Procurement (a tool for publishing information and data relating to PP in the CR). The starting point for PP improvement should be Directive 2014/25/EU of the EP and of the Council of 26th February, 2014, on procurement by entities operating in the water, energy, transport and postal services sectors and repealing Directive 2004/17/EC, that should be transposed into CR legislation by 15th April, 2016.

The PP problems researched by authors can be divided into several thematic groups: PP of innovations, Green PP, public-private partnership, SMEs and their access to PP, electronic procurement, and a critical view of PP legislation.

Some authors focus on PP of innovations (PPI). Dale-Clough $(2015)^{5}$ examined PPI and local authority procurement and suggests conditions for increasing the possibilities for more disruptive innovation through local authority procurement and areas for further research. Amann $(2015)^{6}$ collected some empirical evidence from EU public authorities on barriers for the promotion of PPI. An Irish case study by Davis and Brady (2015) ${ }^{7}$ attempts to answer the question of whether government intentions for the inclusion of innovation and small and medium enterprises (SMEs) in public procurement are being delivered or ignored.

\footnotetext{
${ }^{5}$ Dale-Clough, Lisa (2015).

${ }^{6}$ Amann, Essig (2015).

${ }^{7}$ Davis, Brady (2015).
} 
Another group of problems currently being researched by authors interested in PP is socalled Green PP (GPP). For example, the study by Grandia, Steijn, and Kuipers $(2015)^{8}$ shows first that both affective commitment to implement sustainable procurement and procedural justice increases sustainable procurement behaviour. In addition, their results show that commitment to change acts as a mechanism that fits in with the vision and attitude of ecological sustainability, procedural justice and sustainable procurement behaviour. The findings of a study by Testa et al. (2016) ${ }^{9}$ demonstrate that the relevant limitations linked to the small size of public authorities can be overcome by progress in GPP brought about by several European, national and local supporting initiatives.

SMEs and their access to PP is another topic of significant interest to authors. An analysis of the experiences of SMEs supplying the publicly funded UK heritage sector carried out by Loader and Norton $(2015)^{10}$ demonstrates that the heritage sector has distinct characteristics that affect the public procurement of traditional building skills. The impact of size on small- and medium-sized enterprise public sector tendering by Flynn et al. $(2015)^{11}$ indicates that SMEs are heterogeneous tenderers, and point to the need for more focused research on how SME characteristics influence ability and willingness to tender. There is considerable debate about using so-called public-private partnership (PPP) in PP projects. Ross, Yan (2015) ${ }^{12}$ compares PPPs and traditional PP in the context of efficiency and flexibility. Twenty years of practice in using PPPs in Canada is reflected by Siemiatycki $(2015)^{13}$. The authors' analysis highlights common deal structures, types of risks and responsibilities that are transferred to the private sector, and the significant role that public funding continues to play.

Electronic PP (E-PP) can be represented by Suliantoro et al. $(2015)^{14}$, who predict the social values effect on intentions and the usage behaviour of E-PP and its adoption in government institutions. An empirical investigation by Moretti, Valbonesi (2015) ${ }^{15}$ shows the effects of subcontracting on procurement auction prices in Italy and shows that fully qualified firms in a position to choose whether to subcontract generally offer lower prices than partially qualified firms, which must proceed with mandatory subcontracts.

This study focuses primarily on a critical view of PP legislation in the context of CR PP law and its actual wording, which in fact leads to hidden discrimination against those foreign suppliers willing to submit a bid into CR public tenders.

\footnotetext{
${ }^{8}$ Grandia, Steijn, Kuipers (2015).

9 Testa et al. (2016).

${ }^{10}$ Loader, Norton (2015).

${ }^{11}$ Flynn et al. (2015).

12 Ross, Yan (2015).

13 Siemiatycki (2015).

14 Suliantoro et al. (2015).

15 Moretti, Valbonesi (2015).
} 


\section{Methodology and Data}

The methodological part of the contribution is based mainly on analysis and critical evaluation of the current state of legal issues relating to the proof of qualification of foreign suppliers in PP orders of the CR; with examples of the fairly extensive decisionmaking practices of the Office for the Protection of Competition and law courts, including the jurisprudence of the European Court of Justice. The CA's options are analyzed with regard to the meeting of the requirements of qualification on the part of the candidates, focused on foreign suppliers and their ability to demonstrate competence. Subsequently, a comparative method is employed with regard to the requirements of Czech law on PP in the context of national amendments of the norms on PP in selected EU countries.

The basic foundation of the terms of the current law on PP is Directive 2004/18/EC of the European Parliament and Council of 31st March, 2004, on the coordination of procedures in awarding public sector contracts, public supply contracts and services ${ }^{16}$ (see, e.g. Allain, 2006, or Bovis, 2006) ${ }^{17}$. This directive has now been replaced by Directive 2014/24/EU of the European Parliament and of the Council of 26th February, 2014, on $\mathrm{PP}^{18}$ and the repeal of Directive 2004/18/EC, which the Member States are required to implement into their national directives within two years of their publication in the Official Journal.

The text which follows shows the different ways of demonstrating the qualification of suppliers of different types of PP, firstly from a procedural point of view, both in terms of statutory (mandatory, obligatory) and then from possible (optional) client requirements in documentation to verify the qualification of suppliers. The demonstration of appropriate skills and verification has now received considerable attention in the law ( $\$ 50$ and $\S 67$ of the Act subsequently § 125-143 of the Act).

The gravamen of the work shows the current wording of the law on PP in the CR in the requirements for the qualification of foreign suppliers; at the same time, it is drawn from sources that provide the customary procedural practices of the Czech courts and the European Court of Justice (see above). The data base for the comparative analysis is the basis of the Article defining a single national framework of the PP of selected EU countries neighboring the $\mathrm{CR}$, in particular concerning the requirements for qualification of foreign suppliers. The comparative-law method is used and applied in this paper ${ }^{19}$. Summary data on the number of contracts awarded in the period for foreign suppliers to the authors started from the filtered data database information system, procurement CR, in 2014, data from the European Commission and data obtained from the website of the PP, which is operated by the Ministry of Education, Youth and Sports.

Public purchases encompass an important part of public expenditure in the European Union (EU), according to data from the European Commission ${ }^{20}$ - approx. $14 \%$ of GDP. In the CR, according to the annual report of the Ministry of Regional Development on the

\footnotetext{
${ }^{16}$ Directive of European Parliament and Council 2004/18 / EC of 31st March, 2004.

${ }^{17}$ Allain (2006), Bovis (2006).

${ }^{18}$ Directive 2014/24/EU of the European Parliament and of the Council of 26th February, 2014, on PP.

${ }^{19}$ Sinani, Shanto (2013).

${ }^{20}$ European Commission (2011).
} 
balance of public contracts in 2013, they account for $13-16 \%$ of GDP ${ }^{21}$. A comparison between the proportion of public contracts in GDP of the CR and the average of the EU is provided in the table below.

Table 1: Development of proportion of public contracts in expenses in the EU and CR (in \% GDP)

\begin{tabular}{|l|clllc|}
\hline \multicolumn{1}{|c|}{ Year } & 2009 & 2010 & 2011 & 2012 & 2013 \\
\hline Czech Republic & 15.6 & 15.7 & 13.1 & 12.8 & 12.3 \\
EU average & 14.7 & 14.38 & 13.86 & 13.74 & $*$ \\
\hline
\end{tabular}

* Number was not available

Source: Ministry of Regional Development (2013), European Commission (2011)

Figure 1: Development of proportion of public contracts in expenses in the EU and CR (in \% GDP)

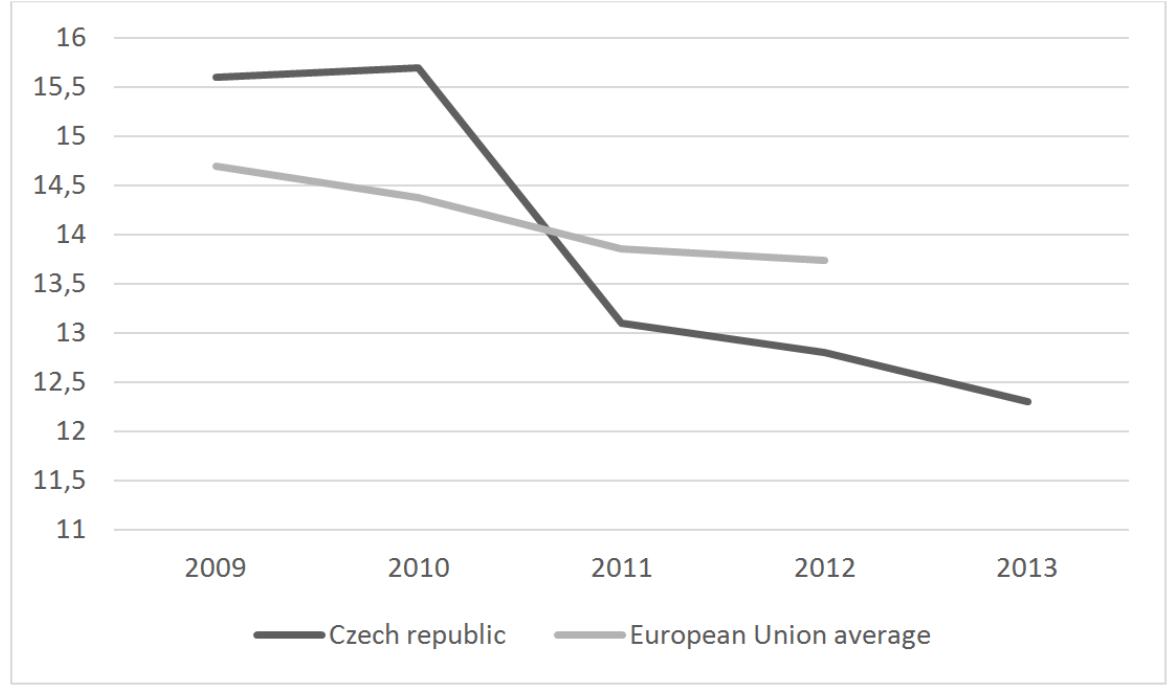

Source: Ministry of Regional Development (2013), European Commission (2011)

Table 2: Total PP expenditure in the EU and CR (in billion euro)

\begin{tabular}{|l|rrrrc|}
\hline Year & \multicolumn{1}{|c}{2009} & 2010 & 2011 & \multicolumn{1}{c}{2012} & 2013 \\
\hline Czech Republic & 24.55 & 24.43 & 23.95 & 22.53 & 21,18 \\
EU total & 1724.02 & 1762.89 & 1750.55 & 1769.58 & $*$ \\
\hline
\end{tabular}

* Number was not available

Source: Ministry of Regional Development (2013), European Commission (2011)

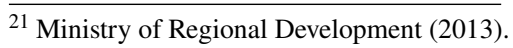


In the CR, PP is dealt with by Act No 137/2006 Coll., On Public Contracts, as amended (the Law or PCL) $)^{22}$. The main reason for the regulation of the public sector and public contracts is to ensure the parallel operation of public markets and private markets. Lawmakers are now becoming aware of the special nature of public markets and are focused on the creation of such conditions as will be similar to the conditions for private-sector operations. ${ }^{23}$ The specific issue that is analyzed in this paper is the possibility under law of the contracting authority (CA) to require appropriate documentation to prove the qualifications of the tender (the supplier submitting a bid in the public tender). The aim of this paper is the determination-analysis of the possible qualification requirements acting as barriers for foreign suppliers in the context of PCL in the CR. A comparison survey regarding qualification requirements in other EU countries is also shown in the text below.

In the CR, many authorities comment upon the individual provisions of the Law inter alia qualification requirements and their authentication, especially by national suppliers. We can cite, for example, Kruták and Krutáková $(2013)^{24}$ or Jurč́k $(2007,2012)^{25}$. It is also necessary to refer to Raus $(2011)^{26}$ and Šebesta et al. (2006) ${ }^{27}$. In the area of the European Union, we can cite Graells (2011) ${ }^{28}$. These authors explain the provisions of the PCL and try to analyze its consequences. We are of the opinion that a critical view of this theme is very important, because in modern society a large number of provisions, sections or paragraphs almost proscribe the choice of the best supplier; foreign suppliers have formidable problems in joining Czech public-tender processes, particularly due to the unnecessary complexity of the entire administration process. In this paper, we would like to focus on the qualification barriers for foreign suppliers that are built in by Czech PCL.

\section{Qualification requirements and their proofing by foreign suppliers}

The wording of the Law (in translation, public contract law, or PCL) means the qualifications meet the eligibility conditions for public contracts (see $\S 17$ letter. E) of the Act). The purpose of the qualification is particularly to check whether the supplier is able to perform the contract to the required standard (Jurčík, 2012) ${ }^{29}$. According to Arrowsmith (2011) ${ }^{30}$ the results are to determine which suppliers are able to perform the contract. In its provisions, the Law divides the different types of qualifications into four basic categories:

\footnotetext{
22 Act No 137/2006 Coll., On Public Contracts, as amended.

23 Bovis (2007).

24 Kruták and Krutáková (2013).

25 Jurčík (2007, 2012).

26 Raus (2011).

27 Šebesta et al. (2006).

${ }^{28}$ Graells (2011).

29 Jurčík (2012).

${ }^{30}$ Arrowsmith (2011).
} 
- basic qualifications,

- professional qualifications,

- technical qualifications,

- economic and financial capacity to meet public demand.

Generally, to qualify, we can say that its use in the context of non-discrimination against potential foreign suppliers (see $\S 6$ ) quite often arises from the specifics of the regulatory process (see, e.g. Rozsudek of KS in Brno 62Ca 15/2009 dated 10th March, 2011), and not only in the CR (see, eg. the judgment of the ECJ C-76/81 dated 10th February 1982, the combined judgments of the ECJ C 27/86 + 28/86 +29/86 dated 9th July, 1987, or the judgment of the ECJ C-315/01).

\section{Basic qualification requirements for a foreign contractor}

The means of demonstrating basic qualification requirements vary depending on the types of procurement (above-threshold, below-threshold, small-scale) or methods of carrying out procurement procedures and, ultimately, by type of authority (public, sector and subsidized). In Table $\mathrm{A}$ in the Appendix there are individual variations and differences in demonstrating basic competences in the context of individual cases, ways of implementing public tenders with reference to the obligation to demonstrate capability, and ways that discriminate against overseas suppliers vis-à-vis domestic suppliers.

\section{Economic and financial competence to implement a public contract by a foreign con- tractor}

Contracting authorities require a compliance statement of financial and economic capacity to fulfil a contract with any kind of tender relating to above- and below-limit public contracts. In the case of a contract within the threshold of PPs for small-scale public contracts, it is the duty of the CA to have evidence demonstrating compliance with this qualification requirement (for former legal requirements for economic and qualifications, see, e.g. Raus and Neruda, 2007)

\section{Qualifications for sector contractor in relation to foreign suppliers}

Proof of qualification is essential for sector contractors ( $\$ 2$ para. 6 of the Act) performing relevant activities (see $\S 4$ ) as is required by law. The paragraph 63 para. 1 of the Act expressly states that "the sector contracting entity is authorized to establish any objective requirements that allow an objective assessment of the qualifications of the supplier". If the sector-contracting entity is required to demonstrate compliance with the requirements for qualification corresponding to one of the basic qualification requirements, it shall be required to demonstrate compliance with these requirements and relevant documents for above-threshold procurement (see Table 3), including requirements for language and date of the documents as may be required by the CA (see also sponsor-subsidized). The two "types" of authorities are therefore legally given a certain arbitrariness in determining the qualification requirements for domestic, and especially for foreign suppliers. 


\section{Professional qualification requirements of a foreign supplier}

Generally speaking, professional qualifications demonstrate the professional competence of a contractor for public contract implementation (Jurčík, 2012). Professional qualifications can be divided into two groups. The first group consists of competences that the contractor must demonstrate in above- or below-threshold tenders (obligatory prerequisites Sec. 4a) and b) of the Act) viz. a copy of the incorporation certificate from the Commercial Register, if the contractor is so registered (no older than 90 days from the opening of the tender process; this also applies to foreign contractors) a copy from another register of similar status (e.g. register of agricultural entrepreneurs, trade register, school register, and similar; however, the latter must conform to the subject matter of the contract, otherwise it is a case of discrimination (see, for example, the decision of the ÚOHS ref. no.: ÚOHS-S151 / 2013 / VZ-15420/2013/521 / VČe dated August 15th, 2013). The second group consists of those that the supplier must approve of only if so provided by specific legislation (optional assumptions, see Sec. 54 letter. c) to e) of the Act). Under these provisions, this concerns the client's requirements for membership in various professional associations (e.g. most frequently the Czech Bar Association, Czech Chamber of Architects, Czech Chamber of Chartered Engineers and Technicians in Construction ČKAIT, Executors Chamber, Chamber of Auditors, Chamber of Tax Advisers) or organizations or professional qualification of persons, by which the contractor demonstrates complicity with these requirements (however, such membership or eligibility may not be necessary for the implementation of a public sector order! - see, e.g., the verdict of the Regional Court in Brno, ref. no. 62 Ca 13/2009 - 67 of April 7th, 2011, or decision of the ÚOHS ref. no. S229 / 2012 / VZ-3516/2013/512 / MVy dated March 14th, 2013). Here, too, in many cases, a foreign supplier is obliged to undertake a more complex procedure than a domestic candidate (see, for example, the registration obligation of a chartered engineer from abroad as persons resident or visiting with ČKAIT for the opportunity to demonstrate professional qualifications). In the case of professional qualifications, foreign suppliers should, however, always verify particular requirements - a business license, membership in a relevant chamber or professional organization or professional competence applicable to the territory of the CR [e.g. Act no. 18/2004 Sb. (Coll.) of recognition of professional qualifications and other eligibility of nationals of Member States of the European Union and some other states and of amendments to some laws (Act on recognition of professional qualifications), as amended].

\section{Technical qualification requirements of a foreign supplier}

First, it is important to note that, as regards technical qualifications, it depends on the CA whether it will require proof of compliance with these qualification requirements (regardless of whether this is a below- or over-threshold limit public order contract). The contractor therefore may or may not have to conform to the requirements for technical qualifications. The law, however, clearly states that the determination of technical qualifications must be commensurate with the object and scope of a public order contract. It is within this area of expertise that there is an extensive decision-making body of information 
on practice and case law, since it is often abused by the CA in the form of "hidden discrimination"; but it is not possible to dispense with them, because they have in specific cases their justification and meaning, and "administrative" contractors use these requirements to prevent unqualified contractors, who would ultimately not be able to comply with the terms of the contract, from participating in the procurement procedures. The obligations of the authority in the event that proof of technical qualification is required is to determine the extent (in which the facts are to be set down), to indicate the type of evidence (such as documents or documents required to demonstrate compliance with the required pre-requisites) and define the minimum level of the qualifications that must invariably correspond to the type, scope and complexity of PP, meaning that suppliers submit documents proving their technical qualifications in this manner.

\section{Foreign supplier scope of qualification proof and documents language}

A key provision for foreign suppliers regarding the authentication of their qualifications is Section 51 paragraph. 7 of the Act in the context of the preceding requirements arising from individual qualification requirements. The first sentences of this provision state, inter alia, that "a foreign contractor evidences his compliance with the qualifications requirement in accordance with the laws applicable in the country of residence, place of business or registration", but contrariwise "to the extent required by law and by the CA". In the view of the authors, this verbal structure already in some ways contradicts itself: on the one hand it gives foreign suppliers the opportunity to demonstrate their qualifications in a manner valid in the country of the company of origin, but on the other introduces an obligation to follow the requirements of the Act and the domestic contractual norms. It should be noted that the wording of this provision is somewhat double-edged. Indeed, if a foreign supplier demonstrates his qualification exactly according to the law of his country of residence, he will be apparently violating the principle of equal standing (in the event that the legislation in the country where the foreign contractor resides is more "lenient"). If we focus on the requirements of Section 53 par. 1 of the Act, it could also mean a breach of the principle of fairness and of equality treatment and that in regarding a minimum of provisions pursuant to Sec. 53 par. 1 letter a), b), f) to h) of the Act.

Documents certifying qualifications processed in the Czech language must always be accepted by the CA, but the latter may, however, stipulate additional tender conditions in that the documents may also be presented in a foreign language. Section 57 par. 1 of the Act also indicates that, if a supplier based according to business address registration for place of business or permanent residence in the $\mathrm{CR}$ or a foreign contractor shall demonstrate compliance with the qualification requirements by means of documentation in a language other than Czech, certified translation into Czech is to be attached unless the conditions in the contract state otherwise, or unless otherwise stated in international treaties. This obligation does not apply to documents in Slovak. The statutory requirement of officiallytranslated documents relating to the proof of qualification of a foreign contractor, however, greatly increases the transaction costs for applicants in the actual bidding process; however, this requirement is in some cases logical because it is not to be presumed that the tendering 
authority will be able to evaluate the qualification document of a foreign supplier, from, for example, Hungary.

\section{Directive 2004/18/EC of the European Parliament and Council in the context of the Czech Act (PCL) and its requirements for a foreign supplier}

The principle of equal treatment and non-discrimination is enshrined in Article 2 of the Directive, while Articles 45 to 48 of Directive govern qualifications. It is important to note, for example, that Article 45, which concerns basic qualifications, does not specify that a foreign contractor has to demonstrate competence both in relation to their own country and that of the CA. According to paragraph 1. a) to d) of Article 45 of the Directive, the CA is obliged to accept an extract from the judicial record or equivalent document that relates to the country of residence of foreign suppliers. This is similar to Article 45.2 e) and f) of the Directive regarding the absence of arrears in taxes and the absence of arrears in social security contributions, in which the option, rather than obligation, is given to exclude a supplier that does not meet these requirements either in qualification under the laws of the country in which he is established or those of the country of the CA. The interpretation of the Directive is that this gives only an opportunity to demonstrate the qualifications for foreign suppliers either in relation to their country of residence, or in relation to the country of the CA, not in relation to both countries, as required by the Czech legislation the provisions of $\S 53$ par. 1 point. a), b), f) to $h$ ) of the Act. It is therefore unquestionable that Czech law is, in this respect, very strict, and the question arises as to whether, in its practical implementation, there is not de facto discrimination against foreign suppliers (cf. Also Arrowsmith, $2011^{31}$ ). For the complexity of the proof of qualification and that only at the level of the basic and professional obligatory requirements of the Act, see Table B in Appendix.

\section{Proof of qualification by inclusion on the list of qualified foreign suppliers}

Given that the equivalent of the Czech list of qualified suppliers or system of certified suppliers may also exist abroad, the CA is obliged to accept such a statement or certificate as proof compliance with the qualification, if

- The statement or certificate is issued in a state that is part of the European Economic Area (obviously including the EU), or in another country under an international agreement concluded by the EU or the CR and at the same time:

- statement or certificate submitted by the supplier, which has its registered office, place of business or residence in the same state in which such a statement or certificate is issued.

It is important to know, however, that such statements or certificates demonstrate the qualifications of foreign suppliers only to the extent that the data referred to in the statement or certificate meets with the requirements of the customer to prove:

${ }^{31}$ Arrowsmith (2011). 
- basic qualification requirements that are relevant to the state with a variant of the basic and professional qualification requirements under the Act, or:

- technical qualification requirements that are analogous in the relevant state qualification requirements pursuant to $\S 56$ par. 1 of the Act, in the case of deliveries, $\S 56$ par. 2 point. a), c) to i) of the Act, in the case of services, and $\S 56$ par. 3 point. a) to c) and points. e) and f) of the Act, in the case of construction work.

The statement from the foreign list must be on the last day of the period on which it can demonstrate qualifications no older than 3 months, while foreign certificates must be valid on the last day of the period for demonstrating the qualification compliance (see also MMR Methodology for Procurement, 2012)

\section{Proof of qualification by statement from the list of qualified suppliers}

Defined in $\S 125-\S 133$ of the Act. This is a document that significantly simplifies the process of demonstration of the basic qualifications and possibly part of the professional qualifications not only for domestic but also for foreign suppliers who regularly compete for domestic orders. Reports can demonstrate all the basic qualifications and authority of the required professional qualification requirements to the extent that they are listed in the appropriate register. There is a currently ruling procedure for registration in the list of qualified supplier by way of Manual Entry in the list of Qualified Suppliers (MMR, 2012). This tool is recommended for use by suppliers who participate in PP on a regular basis, because it greatly simplifies the proof of qualifications, especially for above-threshold PP procedures. It is important, however, that the statement does not date from later than 3 months from the day of the deadline to prove qualification.

\section{Proof of qualification by means of a System of Certified Suppliers}

The system of certified suppliers as described in $\S 133-\S 142$ of the Act can be implemented and operated by any legal entity that creates a system for the attestation and registration of certain parts of the qualification and which system will be approved by the Ministry for Regional Development. This certificate can be obtained by suppliers and may, under the conditions laid down by the particular system, allow suppliers that have demonstrated compliance with basic and certain professional qualifications to demonstrate the fulfilment of certain technical qualifications. The system of certified suppliers is operated by the operator defined by the subject of the procurement (e.g. for suppliers of construction equipment, cleaning services, security services, etc.). The certificate issued within the system of certified suppliers may be submitted by the suppliers within or as part of the evidence of the stated qualification. The legal validity of this certificate is one year. In the context of a system of certified suppliers, it needs to be said that there are currently only a few operators of this system (about six, exclusively focused on suppliers of construction contracts) and suppliers themselves prefer proof of qualification through the above-mentioned list of qualified suppliers. On the PP portal, it is possible to find a methodical procedure to submit an application for inclusion in the system (see Methodology for entering vendor-certified suppliers into the system MMR, 2012). 


\section{A comparative study of the qualification requirements of the Czech legislation and that of neighboring states in relation to foreign suppliers}

\section{Germany}

PP in Germany is regulated by two general laws - Part IV of the Act against Restraints of Competition - Gesetz gegen Wettbewerbsbeschränkungen (GWB) and the Regulation on the Award of Public Contracts - Vergabeverordnung - VGV. Related regulations for PP as individual sectors are Vergabe-Vertragsordnung und für Bauleistungen (VOB), VergabeVertragsordnung und für Leistungen (VOL) Vergabeordnung freiberufliche für Leistungen (VOF), the procurement of defense and security is regulated by the Vergabeverordnung Verteidigung und Sicherheit (VSVgV). German PP legislation is relatively fragmented. If we focus on the civilian sector, which governs the laws VOB (specifically § $6 \mathrm{VOB}$ ), VOL (specifically $\S 7 \mathrm{VOL}$ ) and VOF (specifically $\S 5 \mathrm{VOF}$ ) in individual provisions containing requirements for proof of qualification of suppliers, it is not a requirement that the foreign supplier must have qualification documents to show in respect of both Germany and his domicile. Despite the relative complexity with which German PP legislation abounds, it still does not require a foreign supplier to list his qualifications twice over.

\section{Slovakia}

The Slovak law which regulates PP is Act no. 25/2006 Sb. (Collection), o verejnom obstaravani (hereinafter referred to as "ZVO"). Qualification requirements for foreign applicants are in this Act specifically regulated in $\S 26$ para. 1 and $2 \mathrm{ZVO}$, which does, however, require that the applicant demonstrates basic qualifications only in relation to its domicile. Nowhere is given the legislative requirement for the obligation of applicants based outside the SR to demonstrate compliance with a criminal record of natural or legal persons or absence of tax arrears or arrears in social and health insurance by the foreign supplier in relation to Slovakia and the domicile of the applicant.

\section{Poland}

PP in Poland is regulated by Ustawa z dnia 29 stycznia 2004 r. - Prawo zamówień publicznych (PP Act (Journal of Laws of 2010 No. 113, item 759 and No. 161, item 1078). Qualification requirements are governed by secondary legislation to which to the Polish PP Act refers. Specifically, the Regulation of the Prime Minister of 19th February, 2013, is about the types of documents that may be requested by the CA from the economic operator and the forms in which these documents may be submitted (Journal of Laws of 2013, item 231) and are defined by various potential client requirements which are explicitly laid down. Basic compliance requires extracts from the criminal records of individuals and proof of the qualifications of suppliers. Foreign suppliers (in the "Annex" dedicated to § 4) and legal entities must provide documentation concerning the absence of tax arrears or arrears of social security and health insurance; the Act refers only to foreign supplier equivalent documents in relation to the country of residence, or (if not issued or no obligation exists) to demonstrate this by means of an affidavit. It follows that the Polish PP Act does not require foreign suppliers to demonstrate some dual qualification. 


\begin{abstract}
Austria
As in the previous examples of neighboring states of the CR, Austrian Federal Law no. 17/2006, on PP (Bundesvergabegesetz) enables ( $\$ 68$ paragraph 1, point 6 and 1) foreign suppliers to demonstrate compliance with qualification requirements, the absence of arrears on taxes and social security contributions or in relation to criminal offences concerning Austria or in accordance with the laws of the state in which they are established.
\end{abstract}

\title{
IV. Discussion
}

Currently, emphasis is placed on meeting the principles of $3 \mathrm{E}$ in the context of PP in the EU. With that we are undoubtedly required to ensure effective access to various European public-procurement markets by foreign suppliers and especially in removing administrative barriers to the entry of such suppliers to these markets. One of the main features is the principle of the effectiveness of supplier-selection procurement (Guccio et al., 2014) and possibly effective evaluation in themselves of submitted tenders in PP (Bergman and Lundberg, 2013; Ochrana, 2008). In the context of measuring the effectiveness of the $\mathrm{CR}$, we can then refer to the work related to the economic aspects of procurement, or how public contracts affect the economy of the CR (Pavel, 2007). Somewhat overlooked, however, remain specific assessments associated with the actual effectiveness of legislative barriers that restrict or exclude the direct participation of foreign suppliers in the PP market in the country. In this context it is important to note that the Data Information System on PP shows that in 2014, according to the Bulletin of public contracts, the country awarded 14,987 contracts by means of different types of procurement procedures. From the database OpenData ISVZ (ISVZ), it is possible, after filtering, to determine that, of this number of contracts, there were only 716 public contracts awarded to foreign suppliers (here it is important to mention that 312 procurements of this number fell to defense contracts for repair of aviation artefacts divided into several hundred parts, which significantly affects the result). So we can talk about 400 relevant public-procurement contracts that by 2014 were entered into by Czech foreign suppliers, which is about $2.7 \%$ of all PPs in the country in 2014. After filtering the data outputs obtained from the ISVZ database, we have also found that only $7.63 \%$ of total PP expenditures collected by the PP System in the CR has been allocated to foreign suppliers. Unfortunately, there is no database currently known to the authors of this article that would enable this outcome to be compared with other states whose rules form the basis of our comparative analysis. Table 5 shows the development in the proportion of public contracts awarded to foreign suppliers in 2010-2014 due to the data from ISVZ (information system on PP in the CR). Comprehensive data from ISVZ had to be filtered due to mined relevant information about foreign suppliers. The authors had to delete every Czech supplier out of the comprehensive ISVZ data for each year. After this "filtration" only foreign suppliers were selected and summarized. 
Table 3: Development in proportion of public contracts awarded to foreign suppliers in 2010-2014 based on data from ISVZ (information system on PP in the CR)

\begin{tabular}{|l|ccccc|}
\hline \multicolumn{1}{|c|}{ Year } & 2010 & 2011 & 2012 & 2013 & 2014 \\
\hline Total amount of PP awarded (in billion CZK) & 265.8 & 239.5 & 273.5 & 250.5 & 376.2 \\
Total number of PP awarded & 9663 & 8763 & 10844 & 16327 & 14987 \\
Number of PP awarded to foreign suppliers & 135 & 156 & 256 & 273 & 403 \\
$\begin{array}{l}\text { Total amount of PP awarded to foreign suppliers } \\
\text { (in billion CZK) }\end{array}$ & 12.4 & 31.6 & 15.0 & 29.3 & 28.7 \\
$\begin{array}{l}\text { Proportion in financial amount of all awarded PP to PP } \\
\text { awarded to foreign suppliers (in \%) }\end{array}$ & 4.66 & 13.20 & 5.48 & 11.71 & 7.63 \\
$\begin{array}{l}\text { Proportion in number of all awarded PP to PP awarded } \\
\text { to foreign suppliers (in \%) }\end{array}$ & 1.40 & 1.78 & 2.36 & 1.67 & 2.69 \\
\hline
\end{tabular}

Source: ISVZ + Authors

Figure 2: Development of proportion in number and financial amount of all awarded PP to PP awarded to foreign suppliers (in \%)

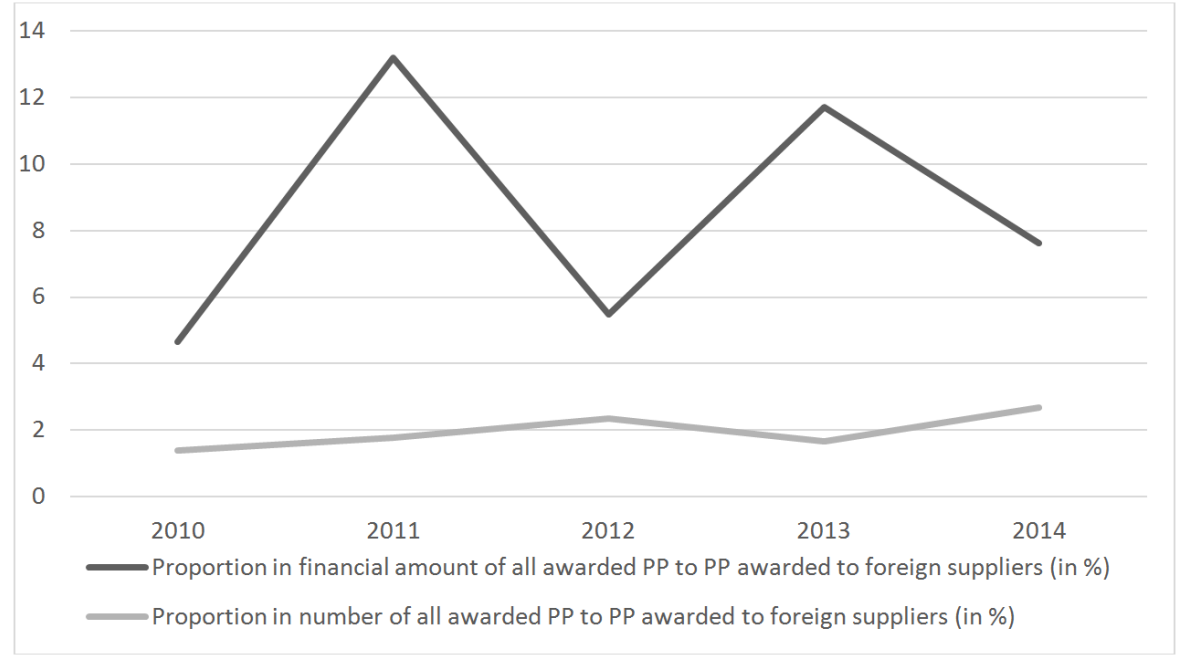

Source: ISVZ + Authors

In Table 5 we can see the development in the total amount of PP awarded (in billion CZK) and registered in ISVZ. This is not the whole amount of all public tenders in CR, but are tenders registered according to PP law in the CR. We can say that approximately half of PP expenses are not rewarded to PP law and are consequently difficult to trace. In 2014, we can see a significant increase in the amount of public PP expenditures registered in ISVZ, from 250.5 billion CZK in 2013 to 376.2 billion CZK in 2014; this could be caused by the higher number of above- and below-threshold public tenders in the CR awarded in open procedure (the most transparent way to carry out PP in the CR). This situation could be caused by the higher expected value of individual awarded tenders. This theory is even 
demonstrated by the number of PP (tenders) in 2014, which was about 1,400 lower than that in 2013 but with a higher value overall.

In Table 5 we can also see an increasing trend in the number of tenders that were awarded to foreign suppliers, from 135 tenders in 2010 to 403 in 2014. This could also be caused by a trend in increasing the total number of PP awarded (9,663 in 2013 and 14,987 in 2014), so the differences the proportion in number of all awarded PP to PP awarded to foreign suppliers in \% are not so significant (1.4\% in 2010 and $2.69 \%$ in 2014). The highest total amount of PP awarded to foreign suppliers was 31.6 billion CZK in 2011. This was mainly the result of large PP tenders by Czech Railways to purchase new trains from Austria (around 200 million EUR). In the last monitored years, 2013 and 2014, we can say that the total amount of PP awarded to foreign suppliers (in billion CZK) was rather balanced.

\section{Conclusion}

Under the present formulation of the Act on PP in the CR and in view of the foregoing, including the comparative analysis of the legislation of PP legislation in neighboring states, it is the opinion of the authors that it is clearly shown that, with regard to the efforts of Czech legislators, emphasis must be placed on the transparency of PP procedures. Dispensing with the de facto elimination of foreign suppliers is becoming a requirement of law at least in respect of proving certain qualification requirements for both domestic and foreign residents engendering redundant and ultimately restrictive competition. The current wording of the Act imposes enormous administrative burdens on the knowledge required by contracting authorities and their representatives, who are always responsible for assessing the bids ${ }^{32}$ and on whose shoulders lies the assessment of the potential supply of foreign contractors, which, due to the variety of possible documents that are not completely necessary, need to have specific expertise and know-how to correct these and carry out the transparent assessment of such offers.

It is highly questionable as to whether the current wording of the Act (PCL) satisfies the principles of Directives on PP EU and whether it meets ESD case law (e.g. Judgment SDEU, Case C-44/96), according to which it is important not to burden potential foreign suppliers of PPs with unnecessary administrative burdens which will ultimately discourage the submission of tenders from "foreign" EU countries.

A new EU Directive on PP EP and Council 2014/24/EU has now come into force. This should be implemented by the national legislatures of the Member States within the next two years as a result of criticism of the administrative burden, especially for proof of qualifications. This Directive should lead to the introduction of a Single European Certificate for PP, which should in future simplify the proof of qualification of foreign suppliers. Such a certificate should show that the holders meet certain basic qualifications without having to substantiate other documents. However, there are questions as to what document's significance will be in practice and how it will be used.

${ }^{32}$ Csorba (2013). 
As an aid to foreign suppliers in orientation-related qualification documents required by individual EU states, the current e-CERTIS tool is employed and operated by the European Commission; however, it is not the responsibility of Member States to regularly update it. This obligation will be introduced by new Directive 2014/24/EU.

In future it will be interesting to continue to address this issue not only in the context of PP in the CR, but inter alia within the European Union, together with the use of the socalled "Good Practice" of non-EU states. To conclude, we note that Czech PP legislation requires further substantial revision in order to open up the procurement market of the CR to foreign suppliers.

\section{References}

Allain, Y. (2006). New European Directives on Public Procurement: Change or Continuity. Public Contract Law Journal, 35(3), 517-536.

Amann, M., Essig, M. (2015). Public procurement of innovation: empirical evidence from EU public authorities on barriers for the promotion of innovation. Innovation - The European Journal of Social Science Research, 28(3), 282-292.

Arrowsmith, S. (2011). The Law of Public and Utilities Procurement (3. ed.). London: Sweet \& Maxwell.

Bergman, M. A. and Lundberg, S. 2013. Tender evaluation and supplier selection methods in public procurement. Journal of Purchasing and Supply Management, 19(2), 73-83.

Bovis, C. (2006). The New Public Procurement Legal Framework. European Public Law, 12(1), 73-109.

Bovis H. Ch. (2007). EU Public Procurement Law. Northampton: Edward Elgar Publishing.

Csorba, C. (2013). Čím se řídí prokazování kvalifikace dodavatelů z EU v zadávacím řízení. Právní rádce, 21(1), 64-65.

Dale-Clough, L. (2015). Public procurement of innovation and local authority procurement: procurement modes and framework conditions in three European cities. Innovation - The European Journal of Social Science Research, 28(3), 220-242.

Davis, P., Brady, O. (2015). Are government intentions for the inclusion of innovation and small and medium enterprises participation in public procurement being delivered or ignored? An Irish case study. Innovation - The European Journal of Social Science Research, 28(3), 324-343.

European Commission. (2011). Internal Procurement market. Retrieved February 15, 2015, from: http://ec.europa.eu/internal_market/publicprocurement/docs/modernising_rules/public-procurement-indicators-2011_en.pdf.

Flynn, A., McKevitt, D., Davis, P. (2015). The impact of size on small and medium-sized enterprise public sector tendering. International Small Business Journal, 33(4), 443-461. Graells, A. S. (2011). Public procurement and the EU competition rules. Oxford: Hart Publishing Ltd.

Grandia, J., Steijn, B., Kuipers, B. (2015). It is not easy being green: increasing sustainable public procurement behaviour. Innovation - The European Journal of Social Science Research, 28(3), 243-260. 
Guccio, C., Pignatoro, G. and Rizzo, I. (2014). Evaluating the efficiency of public procurement contracts for cultural heritage conservation works in Italy: examining the use of locality in public procurement. Journal of Cultural Economics, 38(1), 43-70.

Journal of the European Union. (2015). Judgment of the Court of 15 January 1998. Mannesmann Anlagenbau Austria AG a dalši proti Strohal Rotationsdruck GesmbH. Case C-44/96. Retrieved February 15, 2015, from EUR-Lex [Legal Information System].

Jurčík, R. (2007). Zadávání veřejných zakázek a udělování koncesí v ČR a EU. Praha: C. H. Beck.

Jurčík, R. (2012). Zákon o veřejných zakázkách, Komentář (3. Ed.). Praha: C. H. Beck. Kruták T., Krutáková, L. (2013). Zákon o veřejných zakázkách s komentářem s př́klady. Praha: ANAG.

Loader, K., Norton, S. (2015). SME access to public procurement: An analysis of the experiences of SMEs supplying the publicly funded UK heritage sector. Journal of Purchasing and Supply Management, 21(4), 241-250.

Moretti, L., Valbonesi, P. (2015). Firms' Qualifications and Subcontracting in Public Procurement: An Empirical Investigation. Journal of Law Economics \& Organization, 31(3), 568-598.

Ochrana, F. (2008). Zadávání, hodnocení a kontrola veřejných zakázek: (ekonomická analýza). Praha: Ekopress.

Official Journal of the European Union. (2015). Judgment of the Court of 10 February 1982. SA Transporoute et travaux proti Ministère des travaux publics. Case 76/81. Retrieved February 15, 2015, from EUR-Lex [Legal Information System].

Official Journal of the European Union. (2015). Judgment of the Court (Sixth Chamber) of 9 July 1987. - SA Constructions et entreprises industrielles (CEI) and others v Société coopérative "Association intercommunale pour les autoroutes des Ardennes" and others. - References for a preliminary ruling: Conseil d'Etat-Belgium. - Procedure for the award of public works contracts - Determination of the constructor's financial and economic standing. Joined cases 27/86, 28/86 and 29/86. Retrieved February 15, 2015, from EURLex [Legal Information System].

Official Journal of the European Union. (2015). Judgment of the Court of First Instance (Second Chamber, extended composition) of 21 September 2005. Gesellschaft für Abfallentsorgungs-Technik GmbH (GAT) proti Österreichische Autobahnen und Schnellstraßen AG (ÖSAG). Case C-315/01. Retrieved February 15, 2015, from EUR-Lex [Legal Information System].

Pavel, J. (2007). Ekonomické aspekty veřejných zakázek. Praha: Nakladatelství Oeconomica.

Raus, D. (2011). Zadávání veřejných zakázek: judikatura s komentářem. Praha: Wolters Kluwer ČR.

Raus, D., Neruda, R. (2007). Zákon o veřejných zakázkách, Komentář. Praha: Linde.

Ross, T. W., Yan, J. (2015). Comparing Public - Private Partnerships and Traditional Public Procurement: Efficiency vs. Flexibility. Journal of Comparative Policy Analysis, 17(5), 448-466. 
Siemiatycki, M. (2015). Public - Private Partnerships in Canada: Reflections on twenty years of practice. Canadian Public Administration, 58(3), 343-362.

Sinani, B., Shanto K. (2013). Methods and Functions of Comparative Law. Juridica, 9(2), 25-40.

Suliantoro, H., Ghozali, I., Wibowo, M. A. (2015). E-Procurement adoption in government institution: Predicting social values effect on intention and usage behaviour of e-procurement. International Journal of Business and Society, 16(2), 167-184.

Šebesta, M., Podešva, V., Olík, M. and Machurek, T. (2006). Zákon o veřejných zakázkách s komentářem. Praha: ASPI.

Testa, F., Annunziata, E., Iraldo, F., Frey, M. (2016). Drawbacks and opportunities of green public procurement: an effective tool for sustainable production. Journal of Cleaner Production, 112, 1893-1900.

The Ministry Of Regional Development of the Czech Republic. (2015). Manuál pro zápis do seznamu kvalifikovaných dodavateli Ministerstva pro místní rozvoj (Manual for the registration in the list of qualified suppliers of The Ministry Of Regional Development of the Czech Republic). Retrieved February 15, 2015, from http://portal-vz.cz/cs/Jak-nazadavani-verejnych-zakazek/Metodiky-stanoviska.

The Ministry Of Regional Development of the Czech Republic. (2015). Metodika Ministerstva pro místní rozvoj pro zadávání veřejných zakázek (Methodology of the Ministry of Regional Development for public procurement). Retrieved February 15, 2015, from http://portal-vz.cz/cs/Jak-na-zadavani-verejnych-zakazek/Metodiky-stanoviska.

The Ministry Of Regional Development of the Czech Republic. (2015). Annual Report on Public Tenders in the CR. Retrieved February 15, 2015, from: http://www.portalvz.cz/getmedia/8965ea38-8a96-490b-ad0f-ce4e1c0a32c9/Vyrocni-zprava-o-stavu-verejnych-zakazek-za-rok-2013.pdf.

The Ministry Of Regional Development of the Czech Republic. (2015). Informační systém o veřejných zakázkách. Retrieved February 15, 2015, from http://www.isvz.cz/ISVZ/Podpora/ISVZ_open_data_vZ.aspx.

The Office Of The Protection Of Competition. (2015). Decision of The Office Of The Protection Of Competition of 25 February 2013, e. n. S229/2012/VZ-3516/2013/512/MVy. Retrieved February 15, 2015, from http://www.uohs.cz/cs/verejne-zakazky/sbirky-rozhodnuti/detail-10279.html.

The Office Of The Protection Of Competition. (2015). Decision of The Office Of The Protection Of Competition of 15.8.2013, e. n. ÚOHS-S151/2013/VZ-15420/2013/521/VČe. Retrieved February 15, 2015, from https://www.uohs.cz/cs/verejne-zakazky/sbirky-rozhodnuti/detail-10678.html.

Wolters Kluwer ČR, a.s. (2015). Judgment of the Regional Court in Brno of 10 March 2011, e. n. 62 Ca 15/2009-71. Retrieved February 15, 2015, from ASPI [Legal Information System].

Wolters Kluwer ČR, a.s. (2015). Judgment of the Regional Court in Brno of 7 April, e. $n$. 62 Ca 13/2009-67. Retrieved February 15, 2015, from ASPI [Legal Information System]. 


\section{Appendix}

Table A. Methods and form for proving the basic qualification of foreign supplier with the CA

\begin{tabular}{|c|c|c|c|c|}
\hline Type procurement / tender procedure & $\begin{array}{l}\text { Basic qualification } \\
\text { requirements by: }\end{array}$ & Statutory way of demonstration & Maximum age of document & $\begin{array}{l}\text { Method of proving } \\
\text { qualification by } \\
\text { a foreign supplier }\end{array}$ \\
\hline \multirow{4}{*}{$\begin{array}{c}\text { Valid for these types of proceedings } \\
\text { excess PP: } \\
\text { Open } \\
\text { Narrower } \\
\text { Negotiating procedure with publication } \\
\text { Negotiated procedure without } \\
\text { publication } \\
\text { Negotiations } \\
\text { Dynamic purchasing system } \\
\text { Tender proposal }\end{array}$} & $\begin{array}{l}\text { Sec. } 53 \text { par. } 1 \text { letter a) } \\
\text { and b) of the Act }\end{array}$ & $\begin{array}{l}\text { Extract from the criminal records } \\
\text { of legal entities (PO) (the } \\
\text { Company) and an extract from the } \\
\text { criminal records of individuals } \\
\text { (FO) (persons/persons authorized } \\
\text { to act on behalf of the Contractor)- } \\
\text { for foreign supplier applies that this } \\
\text { requirement must be demonstrated } \\
\text { both in relation to the country of } \\
\text { residence and in relation to the CR! }\end{array}$ & $\begin{array}{l}\text { Not older than } 90 \text { days from } \\
\text { the opening of the tender } \\
\text { process, a request to } \\
\text { participate or preliminary } \\
\text { offer }\end{array}$ & $\begin{array}{l}\text { RT leg.ent in relation to } \\
\text { homeland RT in relation } \\
\text { to homeland (there is no } \\
\text { ČP) } \\
\text { RT PO in rel. to the CR } \\
\text { RT FO in rel. to the CR }\end{array}$ \\
\hline & $\begin{array}{l}\text { Sec. } 53 \text { par. } 1 \text { letter c) to } \\
\text { e) and g), i) to k) ARE of } \\
\text { the Act }\end{array}$ & $\begin{array}{l}\text { affidavit of compliance (must be } \\
\text { signed by the person / persons } \\
\text { authorized to act on behalf of the } \\
\text { Contractor) }\end{array}$ & $\begin{array}{l}\text { Not older than } 90 \text { days from } \\
\text { the opening of the tender } \\
\text { process, requests to participate } \\
\text { or preliminary offer }\end{array}$ & $\begin{array}{l}\text { Affidavit of compliance } \\
\text { (in relation to letter g) in } \\
\text { relation to the homeland } \\
\text { and the CR) }\end{array}$ \\
\hline & $\begin{array}{l}\text { Sec. } 53 \text { par. } 1 \text { letter f) of } \\
\text { the Act }\end{array}$ & $\begin{array}{l}\text { Confirmation of relevant } \\
\text { (supplier's co. seat) Inl. Rev. } \\
\text { Authority on the absence of tax } \\
\text { arrears together with an affidavit of } \\
\text { the absence of arrears on excise } \\
\text { duty - for a foreign contractor, this } \\
\text { requirement must demonstrate the } \\
\text { fact both in relation to the country } \\
\text { of residence and in relation to the } \\
\text { CR! }\end{array}$ & $\begin{array}{l}\text { Not older than } 90 \text { days from } \\
\text { the opening of the tender } \\
\text { process, requests to } \\
\text { participate or preliminary bids }\end{array}$ & $\begin{array}{l}\text { Inland Rev. statement of } \\
\text { arrears in relation to the } \\
\text { homeland (or ČP). Inl. } \\
\text { Rev. statement of arrears } \\
\text { in rel. to the CR (or } \\
\text { ČP)+ČP in rel. to the } \\
\text { excise tax (homeland and } \\
\text { the CR) }\end{array}$ \\
\hline & $\begin{array}{l}\text { Sec. } 53 \text { par. } 1 \text { letter g) } \\
\text { and h) of the Act }\end{array}$ & $\begin{array}{l}\text { Confirmation of the relevant branch } \\
\text { of the Czech Soc. Sec. Admin. } \\
\text { (acc. to the seat of the contractor) } \\
\text { of no arrears on premiums and } \\
\text { penalties for soc. sec. contributions } \\
\text { to the state employment policy for } \\
\text { foreign suppliers applies that this } \\
\text { requirement must demonstrate the } \\
\text { fact both in relation to the country } \\
\text { of residence and in relation to the } \\
\text { CR! }\end{array}$ & $\begin{array}{l}\text { Not older than } 90 \text { days from } \\
\text { the opening of the tender } \\
\text { process, requests to } \\
\text { participate or preliminary bid }\end{array}$ & $\begin{array}{l}\text { A stat. of soc. sec. } \\
\text { admin. in rel. to the } \\
\text { homeland (or ČP) } \\
\text { Stat. Of soc. sec. admin } \\
\text { in rel. to the CR (or ČP) }\end{array}$ \\
\hline
\end{tabular}




\begin{tabular}{|c|c|c|c|c|}
\hline Type procurement / tender procedure & $\begin{array}{l}\text { Basic qualification } \\
\text { requirements by: }\end{array}$ & Statutory way of demonstration & Maximum age of document & $\begin{array}{l}\text { Method of proving } \\
\text { qualification by } \\
\text { a foreign supplier }\end{array}$ \\
\hline \multirow{2}{*}{$\begin{array}{c}\text { Valid for types of proceedings of PP } \\
\text { below the threshold: } \\
\text { Open } \\
\text { Narrower } \\
\text { Negotiating procedure with publication } \\
\text { Negotiating procedure without } \\
\text { publication } \\
\text { Negotiations } \\
\text { Dynamic purchasing system } \\
\text { Tender proposal }\end{array}$} & $\begin{array}{l}\text { Sec. } 53 \text { par. } 1 \text { letter a) to } \\
\text { k) of the Act (proof of } \\
\text { meeting all the basic } \\
\text { qualif. requirements) }\end{array}$ & $\begin{array}{l}\text { The statutory requirement to } \\
\text { demonstrate - affidavit of } \\
\text { compliance (must be signed by the } \\
\text { person / persons authorized to act } \\
\text { on behalf of the Contractor) }\end{array}$ & $\begin{array}{l}\text { Not older than } 90 \text { days from } \\
\text { the opening of the tender } \\
\text { process, requests to } \\
\text { participate or preliminary bids }\end{array}$ & $\begin{array}{l}\text { Affidavit of compliance } \\
\text { (in relation to the point. } \\
\text { A), b), g), f) e) of the Act } \\
\text { in relation to both the CR } \\
\text { and the home of the } \\
\text { applicant) }\end{array}$ \\
\hline & \multicolumn{2}{|c|}{$\begin{array}{l}\text { The offeree has an option to set an obligation of the } \\
\text { contractor to demonstrate the basic qualification } \\
\text { requirements by relevant documents or the obligation to } \\
\text { prove the evidence that at least some of these qualification } \\
\text { requirements were met. }\end{array}$} & $\begin{array}{l}\text { Not older than } 90 \text { days from } \\
\text { the opening of the tender } \\
\text { process, requests to } \\
\text { participate or preliminary bids }\end{array}$ & $\begin{array}{l}\text { In this case, see, by } \\
\text { analogy, pub. } \\
\text { procurement above } \\
\text { threshold }\end{array}$ \\
\hline \multirow{2}{*}{$\begin{array}{l}\text { Simplified below-threshold procedure } \\
\text { Use of an electronic marketplace within } \\
\text { the simplified below-threshold } \\
\text { procedure }\end{array}$} & \multirow[t]{2}{*}{$\begin{array}{l}\text { Sec. } 53 \text { par. } 1 \text { letter a) to } \\
\text { k) of the Act (proof of } \\
\text { meeting all the basic } \\
\text { qual. requirements) }\end{array}$} & $\begin{array}{l}\text { Contractor only submits an } \\
\text { affidavit of compliance (must be } \\
\text { signed by the person / persons } \\
\text { authorized to act on behalf of the } \\
\text { Contractor) }\end{array}$ & \multirow[t]{2}{*}{$\begin{array}{l}\text { Not older than } 90 \text { days } \\
\text { from the opening of the } \\
\text { tender process }\end{array}$} & $\begin{array}{l}\text { Affidavit of compliance } \\
\text { (in relation to letter a), } \\
\text { b), g), f) and e) of the } \\
\text { Act in relation to both } \\
\text { the CR and the home } \\
\text { country of the applicant) }\end{array}$ \\
\hline & & $\begin{array}{l}\text { Prior to contract signature the } \\
\text { contractor must provide originals } \\
\text { or certified copies of all documents }\end{array}$ & & $\begin{array}{l}\text { Before signing the } \\
\text { contract see by analogy } \\
\text { pub.proc. above } \\
\text { threshold }\end{array}$ \\
\hline
\end{tabular}


Table B. Case study of foreign suppliers bidding for above-threshold public tenders in the CR at the minimum legal requirements of the $\mathrm{CA}$ for proof of qualification

\begin{tabular}{|c|c|c|}
\hline $\begin{array}{l}\text { Request contracting } \\
\text { qualification }\end{array}$ & $\begin{array}{l}\text { In relation to the domicile of the applicant } \\
\text { in the Czech language (unless otherwise } \\
\text { specified by the CA) }\end{array}$ & In relation to the $C R$ \\
\hline \multicolumn{3}{|l|}{ Base: } \\
\hline$\S 53$ par. 1 a) of the Act & $\begin{array}{l}\text { statement of the Bundesrepublic Deutschland } \\
\text { Judiciary Office of the Central Trade } \\
\text { Register, that the supplier does not have an } \\
\text { entry with the said office of the, respectively, } \\
\text { criminal record (Auskunft aus dem } \\
\text { Geerbezentralregister) in the original } \\
\text { language with an official translation }\end{array}$ & $\begin{array}{l}\text { Extract from the criminal record of } \\
\text { legal entities }\end{array}$ \\
\hline$\S 53$ par. $1 \mathrm{~b}$ ) of the Act & $\begin{array}{l}\text { statement of the Bundesrepublic Deutschland } \\
\text { Judiciary Office of the Central Trade } \\
\text { Register, the statutory representative (s) in } \\
\text { supplier has no entry registration with the } \\
\text { Office of the, respectively, criminal record } \\
\text { (Fuhrungzeugnis) in the original language } \\
\text { with an official translation }\end{array}$ & $\begin{array}{l}\text { Extract from the criminal records } \\
\text { of individuals or statutory } \\
\text { representative. }\end{array}$ \\
\hline$\S 53$ par. $1 \mathrm{c}$ ) to e) & $\begin{array}{l}\text { Affidavit in the Czech language signed by the } \\
\text { statutory body(ies) }\end{array}$ & $\begin{array}{l}\text { Affidavit in the Czech language } \\
\text { signed by the statutory body(ies) }\end{array}$ \\
\hline \multirow[t]{2}{*}{$\S 53$ par. $1 \mathrm{f}$ ) of the Act } & $\begin{array}{l}\text { Confirmation the local tax office in } \\
\text { Deutschland (Finanzveraltung) the absence of } \\
\text { tax arrears foreign supplier in the original } \\
\text { language with an official translation }\end{array}$ & $\begin{array}{l}\text { Confirmation of the tax office (by } \\
\text { location) re the absence of tax } \\
\text { authorities of arrears at the } \\
\text { Financial Administration of the CR }\end{array}$ \\
\hline & $\begin{array}{l}\text { In relation to the excise tax affidavit in the } \\
\text { Czech language signed by the statutory } \\
\text { body(ies) }\end{array}$ & $\begin{array}{l}\text { In relation to the excise tax } \\
\text { affidavit in the Czech language } \\
\text { signed by the statutory body(ies) }\end{array}$ \\
\hline$\S 53$ par. 1 point. g) of the Act & $\begin{array}{l}\text { Affidavit in the Czech language signed by the } \\
\text { statutory body(ies) }\end{array}$ & $\begin{array}{l}\text { Affidavit in the Czech language } \\
\text { signed by the statutory body(ies) }\end{array}$ \\
\hline$\S 53$ par. $1 \mathrm{~h}$ ) of the Act & $\begin{array}{l}\text { A certificate of successful completion of the } \\
\text { payment obligations by the respective health } \\
\text { insurance company foreign supplier in the } \\
\text { original language with an official translation } \\
\text { (Unbedenklichkeitsbescheininung) }\end{array}$ & $\begin{array}{l}\text { Confirmation of the Social Security } \\
\text { Administration of the absence of } \\
\text { arrears for social security and state } \\
\text { employment policy, penalty and } \\
\text { surcharge on premiums }\end{array}$ \\
\hline$\S 53$ par. $1 \mathrm{~g}$ ) and $\mathrm{h}$ ) of the Act & $\begin{array}{l}\text { Affidavit in the Czech language signed by the } \\
\text { statutory body(ies) }\end{array}$ & $\begin{array}{l}\text { Affidavit in the Czech language } \\
\text { signed by statutory body(ies) }\end{array}$ \\
\hline \multicolumn{3}{|l|}{ Professional (obligatory): } \\
\hline$\S 54$ a) of the Act & $\begin{array}{l}\text { A copy of the Commercial Register of the } \\
\text { relevant foreign supplier in the original } \\
\text { language with an official translation } \\
\text { (Wiedergabe des aktuellen Registerinhalts) }\end{array}$ & Not required \\
\hline$\S 54 \mathrm{~b}$ ) of the Act & Includes the above-mentioned document & Not required \\
\hline
\end{tabular}

